\title{
The Decomposition of Goods and Services in a Block Structural Path Analysis in the Indonesian Economy ${ }^{\dagger}$
}

\author{
Nuzul AchjaR*, Geoffrey J.D. Hewings** and Michael Sonis***
}

\begin{abstract}
The purpose of this paper is to reveal the magnitude of the relationship between goods and service sector that is originally grouped into production activities in a social accounting matrix (SAM) framework. The decomposition of production activities into goods and services in 1995 and 1998 Indonesian SAM provide other features and interpretation on the structural changes in the Indonesian economy. Using block structural path analysis (BSPA) that traces feedback loop effects, there is evidence of the dominant role of the goods sector in generating factorial and institutional incomes in the Indonesian economy. This paper argues that the magnitude of the linkages between goods and services might have characterized a strong dependency of services on the goods sector, opposing those of typical developed countries that believe services might be relatively independent from goods sectors. Prior to the decomposition of goods and services, general pattern of the structural change in the Indonesian economy using 1975-1999 aggregated SAM will be presented.
\end{abstract}

\section{Introduction}

Earlier work of Sonis et al. [17] evaluated changes in the Indonesian economy during the period 1975-1985 by analyzing the change in the structure of output, factorial and institutional incomes, and the change in the hierarchy of direct coefficients of production activities. Using a series of 1975-1985 Indonesian SAMs consisting of five aggregated production activities, two and three types of factors and institutions respectively, they found that block structural path analysis (BSPA) proved to be useful in contributing to the basic understanding in the processes of identifying change within a social accounting framework. Using 1975-1999 aggregated SAM data $(13 \times 13)$, Achjar et al. [1] extended the Sonis et al. [17] analysis by examining the role of past and current policies that might have affected the structural changes in the Indonesian economy, before and after Indonesian economic crisis in mid-1997. BSPA method is proposed as a complement, not as a replacement to the more familiar forms of structural path analysis (SPA) as suggested by Khan and Thorbecke [9], Defourny and Thorbecke [7] who focus on the micro level of analysis of individual paths.

The foundation of the modern economy has shifted from the production of merchandise such as agricultural products and manufactured goods to the service sector. Many studies have highlighted the important role the service sector plays as a prerequisite for economic

+ The comments of participants at the Japan Section RSAI meeting at Waseda University in September 2004 are acknowledged, especially those provided by Takahiro Akita.

* LPEM, University of Indonesia, Jakarta

** Regional Economics Applications Laboratory, University of Illinois, Urbana

*** Department of Geography, Bar Ilan University, Ramat Gan, Israel and Regional Economics Applications Laboratory, University of Illinois, Urbana 
development (Riddle [15] ; Bailly, A.S. et al. [4] ; Bailly, A.S. and Coffey [5] ; Behuria, S. and R. Khullar [6]). Stahl [19] observed the structural changes in the economies of all 21 APEC countries, including Indonesia; at the highest levels of per capita income, the income elasticity of demand for manufacturers declines marginally while the demand for services such as tourism, restaurants, health, education and banking and finance absorbs a proportionately larger share of per capita income. The declining share of manufacturing in GDP and the rising contribution of services reflects changes in the division of labor over time. More accountancy, legal, and engineering services, transport, financial and insurance needs are required that are often purchased from other companies.

Although most of the arguments on structural changes recognized the increasing share of services in total employment and GDP; however, the magnitude of the linkages between goods and services, and how the influence of each of these two sectors generates factorial and institutional incomes in the Indonesian economy has not comprehensively explored. The purpose of this paper is to reveal the nature of the linkages between goods and services, and how each has contributed to the changes in the structure of the Indonesian economy, particularly between 1995 and 1998 .

\section{Goods Producing and Service Sector in the Indonesian Economy}

It has been widely recognized that prior to the economic recession in mid-1997, Indonesia had become one of the most rapidly growing economies in the Asia and Pacific region. Over the period 1975-95, average economic growth reached 6 to $7 \%$ annually, and income per capita rose by $4-5 \%$. During the same period, the declining share of agricultural sector, the increasing contribution of manufacturing industries to GDP, and the changes in labor market structure have characterized the more important structural changes in the Indonesian economy. One of the striking features of the Indonesian economy was the declining share of agriculture sector from $36.8 \%$ GDP in 1975 to $16.1 \%$ in 1995, although it increased to $17.4 \%$ in 1999, almost two years after the crisis. The share of manufacturing (processing industries) increased from $10.9 \%$ in 1975 to $23.9 \%$ and $25.7 \%$ GDP in 1995 and 1999 respectively.

The share of services (including construction and utilities) increased from $41.2 \%$ in 1975 to $50.7 \%$ in 1995 , but declined to $47.0 \%$ GDP in 1999 . The largest share of the service sector was contributed by trade, hotel and restaurant (14-17\% GDP during 1975-99 period), whereas other services account for $8-12 \%$ GDP. Transportation service contributes $4-7.5 \%$ and financial services $4-9 \%$. Before the crisis, one of the most rapidly growing service sectors was financial services, the expansion generated by financial liberalization in the 1988. The trade sector is dominated by petty trade, mainly self-employed and family work (including stalls, market traders and hawkers that are responsible for about $40 \%$ of total employment in services in the mid 1980s (Manning [10]). It was not difficult to argue that the Indonesian service economy was largely shaped by small and informal enterprises.

Alexander and Booth [2] underlined the important role of service sector played in the Indonesian economy in past decades. Indonesia was net importer of service sector because the lack of competitiveness in consulting and professional services. The only positive account was contributed by tourism but, in general, the service sector did contribute to the absorption of employment and in GDP growth. The service sector encompasses wholesale, 
retail, hotels and restaurants, transport and communications, financial, and professional services, and public, domestic, and community services. Further, Alexander and Booth [2] argued that the rapid growth of employment in the service sector was due to the large of share of government employment. The role of government focused on the provision of public services such as health and education. In the 1970s, as oil and gas revenues grew and budgetary expenditures accelerated, the government embarked on an ambitious program of economic and social infrastructure development which necessitated the recruitment not just of administrative and clerical staff but also of a wide range of skilled workers, including teachers, health workers, engineers, economists, statisticians, and financial managers. In 1975 almost $60 \%$ of all permanent government employees had at most lower secondary education, and by 1999 this had fallen under $30 \%$.

\section{Decomposition of Three Economic Subsystems}

While the analysis of the structural changes in the economy using $\mathrm{SPA}^{1}$ focuses more on individual sectors with a highly disaggregated matrix, the BSPA offers a macro perspective to trace the magnitude of the influence departing from an initial injection of an economic subsystem in a way that the transfer of influence to other corresponding economic subsystems provides a feedback loop effect to other corresponding subsystems - in other words, an augmentation process in the whole economic system. Figure 1 provides a general overview of the difference between SPA and BSPA.

One of the advantages of using BSPA is to separate the influence of one economic subsystem in the whole system. The SAM can be decomposed in such a way that selfinfluence and induced self-influence can be detected. Sonis and Hewings [18] extended the idea of self-influence and induced self-influence for a SAM in similar fashion to the decomposition of three regions into subsystems. Given a matrix of direct coefficients $A$, exogenous final demand $d$ and total output $x$ for a SAM framework, the system can be presented:

$$
A=\left[\begin{array}{ccc}
0 & 0 & A_{13} \\
A_{21} & A_{22} & 0 \\
0 & A_{32} & A_{33}
\end{array}\right] ; \quad d=\left[\begin{array}{c}
0 \\
d_{1} \\
d_{A}
\end{array}\right] ; \quad x=\left[\begin{array}{l}
x_{1} \\
x_{2} \\
x_{3}
\end{array}\right]
$$

The subscripts refer, respectively, to the usual tripartite division of a social accounting matrix into submatrices of factors (1), institutions (2) and activities (3) that can be decomposed as :

$$
A=\left(\begin{array}{ccc}
0 & 0 & 0 \\
A_{21} & 0 & 0 \\
0 & 0 & 0
\end{array}\right)+\left(\begin{array}{ccc}
0 & 0 & 0 \\
0 & A_{22} & 0 \\
0 & A_{32} & 0
\end{array}\right)+\left(\begin{array}{ccc}
0 & 0 & A_{13} \\
0 & 0 & 0 \\
0 & 0 & A_{33}
\end{array}\right)=A_{1}+A_{2}+A_{3}
$$

where, the matrices $A_{1}, A_{2}, A_{3}$ represent the direct inputs of factors, institutions and activities separately from which a decomposed inverse can be presented:

$$
B=(I-A)^{-1}=G_{3} G_{2} G_{1}
$$

Decomposition (3) differs from the multiplicative decomposition of Pyatt and Round

\footnotetext{
${ }^{1}$ See for example, a recent study by Azis [3] on the application of SPA in the Indonesian economy.
} 

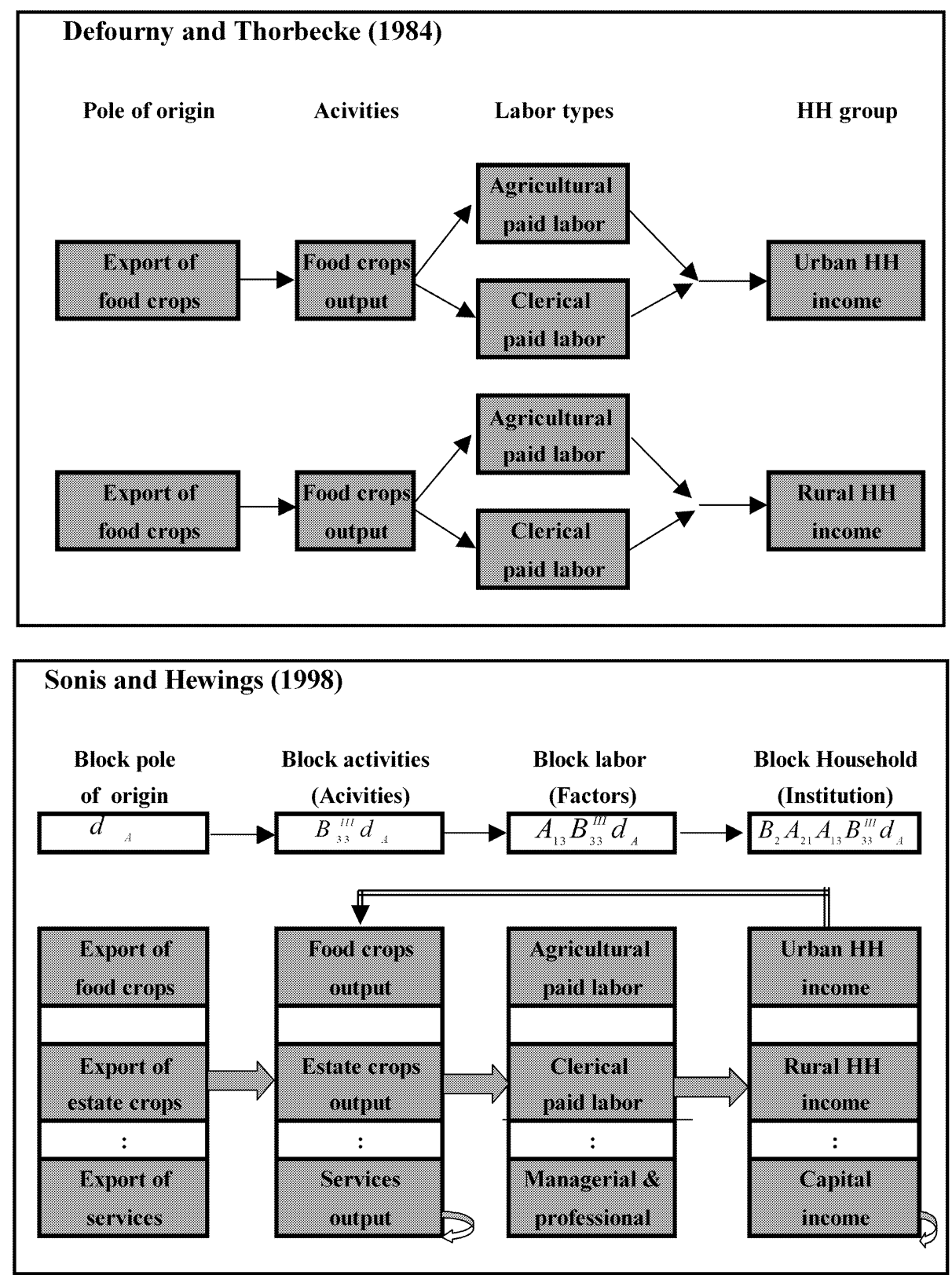

Figure 1. The Path from Origin to Destination of a SPA in SAM Framework

[14] that was primarily purposed to recognize own direct-effect, indirect self-influence and synergic cross effect by dividing matrix $A$ into diagonal and off-diagonal elements and exploiting the properties of permutation matrices. In their system, the generalized inverse is decomposed as follows :

$$
(I-A)^{-1}=M_{3} M_{2} M_{1}
$$

where, 


$$
\begin{array}{ll}
M_{1}=\left(I-A_{1}\right)^{-1} & \text { own direct effect } \\
M_{2}=\left\{I-\left[\left(I-A_{1}\right) A_{2}\right]^{3\}}\right\}^{-1} & \text { indirect self influence } \\
M_{3}=I+\left(I-A_{1}\right) A_{2}+\left[\left(I-A_{1}\right) A_{2}\right]^{2} & \text { synergetic cross effects }
\end{array}
$$

Defourny and Thorbecke [7] proposed an additive decomposition for tracing the influence of economic subsystem :

$$
(I-A)^{-1}=I+\left(M_{1}-I\right)+\left(M_{2}-I\right) M_{1}+\left(M_{3}-I\right) M_{2} M_{1}
$$

Sonis and Hewings [18] converted the additive decomposition (5) into a multiplicative form of a block matrix of direct inputs for three-region or economic subsystems:

$$
A=\left[\begin{array}{lll}
A_{11} & A_{12} & A_{13} \\
A_{21} & A_{22} & A_{23} \\
A_{31} & A_{32} & A_{33}
\end{array}\right]
$$

and the corresponding Leontief inverse,

$$
B=(I-A)^{-1}=\left[\begin{array}{lll}
B_{11}^{I I I} & B_{12}^{I I I} & B_{13}^{I I I} \\
B_{21}^{I I I} & B_{22}^{I I I} & B_{23}^{I I I} \\
B_{31}^{I I I} & B_{32}^{I I I} & B_{33}^{I I I}
\end{array}\right]
$$

However matrix (6) does not separate the influence of economic subsystems from other sub-systems. In order to separate the influence of each three region (block matrices), the Schur-Banachiewicz inverse for a pair of sub-systems is used.

Consider the row and column containing $A_{33}$ in equation (6) that represents the domain of the block matrix (3). The formation of partial block matrix, such as the pair of block matrix (1) and (2) is considered as the domain of block matrix (3). Here, the direct inputs under the domain of (3) can be written as:

$$
A(3)=\left[\begin{array}{ll}
A_{11} & A_{12} \\
A_{21} & A_{22}
\end{array}\right]
$$

Define Schur-Banachiewicz's partial block matrix as $(S)$. The corresponding partial Leontief inverse is defined as:

$$
\begin{aligned}
B(S)=[I-A(S)]^{-1} & =\left[\begin{array}{ll}
B_{11}^{I I}(S) & B_{12}^{I I}(S) \\
B_{21}^{2}(S) & B_{22}^{2}(S)
\end{array}\right]=\left[\begin{array}{cc}
B_{11}^{I I}(S) & B_{11}^{I I}(S) A_{12} B_{2} \\
B_{22}^{2}(S) A_{21} B_{1} & B_{22}^{I I}(S)
\end{array}\right] \\
& =\left[\begin{array}{cc}
B_{11}^{I I}(S) & B_{1} A_{12} B_{11}^{I I}(S) \\
B_{2} A_{21} B_{22}^{I I}(S) & B_{22}^{I I}(S)
\end{array}\right]
\end{aligned}
$$

Superscript II in (9) denotes a two-region or a two-block matrix of economic system that characterize the nature of feedback loop process within the system. Based on the partial Leontief inverse for pair $(1,2)$, the element of the Schur-Banachiewincz inverse matrix in a three-economic-subsystems is presented as the following (for proofs, see Sonis and Hewings [18]) :

$$
B=\left[\begin{array}{ccc}
B_{11}^{I I I} & B_{11}^{I I I} A_{12}^{I I I} B_{22}^{I I}(1) & B_{11}^{I I I} A_{13}^{I I I} B_{33}^{I I}(1) \\
B_{22}^{I I I} B_{21}^{I I I} B_{11}^{I I}(2) & B_{22}^{I I I} & B_{22}^{I I I} A_{23}^{I I I} B_{33}^{I I}(2) \\
B_{33}^{I I I} A_{31}^{I I I} B_{11}^{I I}(3) & B_{33}^{I I I} A_{32}^{I I I} B_{22}^{I I}(3) & B_{33}^{I I I}
\end{array}\right]
$$

Consider Yamada and Ihara [20], Ihara [8] augmented inputs for three-region or three 
economic subsystems :

$$
A_{i j}^{I I I}=A_{i j}+A_{i s} B_{s} A_{s j} \quad i \neq j, i \neq s ; i, j, s=1,2,3
$$

and the extended regional Leontief inverses :

$$
B_{i i}^{I I I}=\left[I-A_{i i}-A_{i j} B_{j j}^{I I}(i) A_{j i}^{I I I}-A_{i s} B_{s s}^{I I}(i) A_{s i}^{I I I}\right]^{-1} \quad i \neq j, i \neq s, j \neq s ; i, j, s=1,2,3
$$

The corresponding augmented Schur complement that captures economic self-influence and as the result of the augmentation of inputs from other subsystems can be written as:

$$
S_{i}=A_{i i}+A_{i j} B_{j j}^{I I}(i) A_{j i}^{I I I}+A_{i s} B_{s s}^{I I}(i) A_{s i}^{I I I}
$$

The augmentation of inputs (13) leads to the detailed structure of augmentation in the Schur complement :

$$
\begin{array}{r}
S_{i}=A_{i i}+A_{i j} B_{j j}^{I I}(i) A_{j i}+A_{i s} B_{s s}^{I I}(i) A_{s i}+A_{i j} B_{j j}^{I I}(i) A_{j s} B_{s} A_{s i}+A_{i s} B_{s s}^{I I}(i) A_{s j} B_{j} A_{j i} \\
i \neq j, i \neq s \quad j \neq s ; i, j, s=1,2,3
\end{array}
$$

Thus, in the three-block system, the self-influence of a block comprise the superposition of (i) circulation (direct self-influence) ; (ii) self-influence generated through bilateral block interdependencies and (iii) self-influence promoted by tri-lateral block interdependencies. The expressions (13) and (14) reflect the existence of a nested hierarchy of different levels of augmentation represented in the recursive form in (10); in a sense, the process resembles the Matrioshka idea introduced by Sonis and Hewings [16]. Furthermore, using Miyazawa ([11], [12]) fundamental equations for the case of three regions, the transfer of influence from region $j$ to $i$ can be defined as :

$$
B_{i j}^{I I}=B_{i i}^{I I I} A_{i j}^{I I I} B_{j j}^{I I}(i)=B_{i i}^{I I}(j) A_{i j}^{I I I} B_{j j}^{I I I} \quad i \neq j, i, j=1,2,3
$$

The augmented Schur complement (14) can also be written as :

$$
S_{i}=A_{i i}+A_{i j}^{I I I} B_{j j}^{I I}(i) A_{j i}+A_{i s}^{I I I} B_{s s}^{I I I}(j) A_{s i}
$$

The expressions (15) and (16) offer the option of presenting the Leontief inverse for the three-block system in an alternative form :

$$
B=\left[\begin{array}{ccc}
B_{11}^{I I I} & B_{11}^{I I}(2) A_{12}^{I I} B_{22}^{I I} & B_{11}^{I I}(3) A_{13}^{I I I} B_{33}^{I I I} \\
B_{22}^{I I}(1) B_{21}^{I I I} B_{11}^{I I I} & B_{22}^{I I I} & B_{22}^{I I}(3) B_{23}^{I I I} B_{33}^{I I I} \\
B_{33}^{I I}(1) A_{31}^{I I I} B_{11}^{I I I} & B_{33}^{I I I}(2) B_{32}^{I I I} B_{22}^{I I I} & B_{33}^{I I I}
\end{array}\right]
$$

The generalizations (16) and (17) can be transferred from the meso-level of regions to the higher macro-level of the inner and outer left and right block matrix multipliers. For example, for the left multipliers :

$$
\begin{aligned}
& B=\left[\begin{array}{ccc}
B_{11}^{I I I} & 0 & 0 \\
0 & B_{22}^{I I I} & 0 \\
0 & 0 & B_{33}^{I I I}
\end{array}\right]\left[\begin{array}{ccc}
I & A_{12}^{I I I} B_{22}^{I I}(1) & A_{13}^{I I} B_{33}^{I I}(1) \\
A_{21}^{I I I} B_{11}^{I I}(2) & I & A_{23}^{I I} B_{33}^{I I}(2) \\
A_{31}^{I I I} B_{11}^{I I}(3) & A_{32}^{I I I} B_{22}^{I I}(3) & I
\end{array}\right] \\
& =\left[\begin{array}{ccc}
B_{11}^{I I L} & 0 & 0 \\
0 & B_{22}^{I I L L} & 0 \\
0 & 0 & B_{33}^{I I L L}
\end{array}\right]\left[\begin{array}{ccc}
B_{1} & 0 & 0 \\
0 & B_{2} & 0 \\
0 & 0 & B_{3}
\end{array}\right]\left[\begin{array}{ccc}
I-A_{11} & A_{12}^{I I I} B_{22}^{I I L}(1) & A_{13}^{I I I} B_{33}^{I I L}(1) \\
A_{21}^{I I I} B_{11}^{I I L}(2) & I-A_{22} & A_{23}^{I I I} B_{33}^{I I L}(2) \\
A_{31}^{I I I} B_{11}^{2 L}(3) & A_{32}^{I I I} B_{22}^{I I L}(3) & I-A_{33}
\end{array}\right]\left[\begin{array}{ccc}
B_{1} & 0 & 0 \\
0 & B_{2} & 0 \\
0 & 0 & B_{3}
\end{array}\right]
\end{aligned}
$$

Augmented input of the blocks in the SAM are: 


$$
\begin{array}{ll}
A_{12}^{I I I}=A_{13} B_{3} A_{32} ; & A_{13}^{I I I}=A_{13} ; \\
A_{21}^{I I I}=A_{21} ; & A_{23}^{I I I}=A_{21} A_{13} ; \\
A_{31}^{I I I}=A_{32} B_{2} A_{21} ; & A_{32}^{3}=A_{32}
\end{array}
$$

The extended self-influence Leontief inverses at each block are:

$$
\begin{aligned}
& B_{11}^{I I I}=\left[I-A_{13} B_{3} A_{32} B_{2} A_{21}\right]^{-1} \\
& B_{22}^{I I I}=\left[I-A_{22}-A_{21} A_{13} B_{3} A_{32}\right]^{-1} \\
& B_{33}^{I I I}=\left[I-A_{33}-A_{32} B_{2} A_{21} A_{13}\right]^{-1}
\end{aligned}
$$

The corresponding augmented complements:

$$
\begin{aligned}
& S_{1}=A_{13} B_{3} A_{32} B_{2} A_{21} \\
& S_{3}=A_{22}+A_{21} A_{13} B_{3} A_{32} \\
& S_{3}=A_{33}+A_{32} B_{2} A_{21} A_{13}
\end{aligned}
$$

have the economic network structure associated with the blocks $A_{22}, A_{33}$ and with the components of the quasi-permutation matrix of direct inputs :

Drawing on (19), the Leontief inverse for this SAM has a form:

$$
\begin{aligned}
B & =\left[\begin{array}{ccc}
B_{11}^{I I I} & A_{13} B_{3} A_{32} B_{22}^{I I I} & A_{13} B_{33}^{I I I} \\
B_{2} A_{21} B_{11}^{I I I} & B_{22}^{I I I} & B_{2} A_{21} A_{13} B_{33}^{I I I} \\
B_{3} A_{32} B_{2} A_{21} B_{11}^{I I I} & B_{3} A_{32} B_{22}^{I I I} & B_{33}^{I I I}
\end{array}\right] \\
& =\left[\begin{array}{ccc}
I & A_{13} B_{3} A_{32} & A_{13} \\
B_{2} A_{21} & I & B_{2} A_{21} A_{13} \\
B_{3} A_{32} B_{2} A_{21} & B_{3} A_{32} & I
\end{array}\right]\left[\begin{array}{ccc}
B_{11}^{I I I} & 0 & 0 \\
0 & B_{22}^{I I I} & 0 \\
0 & 0 & B_{33}^{3}
\end{array}\right]
\end{aligned}
$$

At the meso level for the major divisions of the economy :

$$
\begin{aligned}
B d & =\left[\begin{array}{ccc}
B_{11}^{I I I} & A_{13} B_{3} A_{32} B_{22}^{I I I} & A_{13} B_{33}^{I I I} \\
B_{2} A_{21} B_{11}^{I I I} & B_{22}^{I I I} & B_{2} A_{21} A_{13} B_{33}^{I I I} \\
B_{3} A_{32} B_{2} A_{21} B_{11}^{I I} & B_{3} A_{32} B_{22}^{I I I} & B_{33}^{I I I}
\end{array}\right]\left[\begin{array}{c}
0 \\
d_{I} \\
d_{A}
\end{array}\right] \\
& =\left[\begin{array}{c}
A_{13} B_{3} A_{32} \\
I \\
B_{3} A_{32}
\end{array}\right] B_{22}^{I I I} d_{I}+\left[\begin{array}{c}
A_{13} \\
B_{2} A_{21} A_{13} \\
I
\end{array}\right] B_{33}^{I I I} d_{A}
\end{aligned}
$$

The expression (23) reveals the major paths of influence in the transmission of economic impulses. Within the blocks, the individual paths are still preserved; in other words, the portraits of individual trees are still preserved in the forest picture of BSPA. The network complication initially injected by the final demand of institutions $\left(d_{I}\right)$ and production activities $d_{A}$ and the following transformation are shown as,

$$
\begin{aligned}
& \text { a). Institutions : } d_{I} \rightarrow B_{22}^{I I I} d_{I} \rightarrow B_{3} A_{32} B_{22}^{I I I} d_{I} \rightarrow A_{13} B_{3} A_{32} B_{22}^{I I I} d_{I} \\
& \text { b). Activities : } d_{A} \rightarrow B_{33}^{I I I} d_{A} \rightarrow A_{13} B_{33}^{I I I} d_{A} \rightarrow B_{2} A_{21} A_{13} B_{33}^{I I I} d_{A}
\end{aligned}
$$

Drawing on the previous work of Achjar et al. [1], the general pattern of the structural changes in the Indonesian economy using aggregated SAMs for 1995-1999 are displayed in tables $1 \mathrm{a}, \mathrm{b}$ and figures $2 \mathrm{a}, \mathrm{b}$. Table $1 \mathrm{a}$ and figure $2 \mathrm{a}$ show the value of initial injection from institutions and its transformation to the distribution of households, firms and government incomes, and its subsequent effects to the output of production activities, then to labor and capital incomes ${ }^{2}$. Table $1 \mathrm{~b}$ and figure $2 \mathrm{~b}$ shows the injection and transformation from 
Table 1a. Transformation From Institution to Activities and Factors, 1975-99 (\%)

\begin{tabular}{|l|c|r|r|r|r|c|}
\hline $\begin{array}{c}\text { F. DEMAND } \\
\text { INSTITUTION }\end{array}$ & 1975 & 1980 & 1985 & 1990 & 1995 & 1999 \\
\hline Households & 0 & 25.0 & 11.3 & 16.7 & 12.1 & 10.8 \\
\hline Firms & 4.7 & 11.3 & 8.9 & 24.6 & 23.1 & 0.0 \\
\hline Government & 95.3 & 63.7 & 79.8 & 58.7 & 64.8 & 89.2 \\
\hline \multicolumn{1}{|c|}{ Total } & 100 & 100 & 100 & 100 & 100 & 100 \\
\hline
\end{tabular}

\begin{tabular}{|l|c|c|c|c|c|c|}
\hline $\begin{array}{c}\text { INSTITUTION } \\
\text { OUTPUT }\end{array}$ & 1975 & 1980 & 1985 & 1990 & 1995 & 1999 \\
\hline Households & 45.3 & 48.9 & 50 & 44.4 & 43.1 & 37.5 \\
\hline Firms & 17 & 20.3 & 17.9 & 18.7 & 19.1 & 7.5 \\
\hline Government & 37.7 & 32.8 & 32.1 & 37.0 & 37.8 & 55.0 \\
\hline Total & 100 & 100 & 100 & 100 & 100 & 100 \\
\hline
\end{tabular}

\begin{tabular}{|l|r|r|r|r|r|c|}
\hline $\begin{array}{c}\text { ACTIVITIES } \\
\text { OUTPUT }\end{array}$ & 1975 & 1980 & 1985 & 1990 & 1995 & 1999 \\
\hline Food crops & 43.2 & 40 & 36.8 & 30.1 & 27.4 & 28.3 \\
\hline Estate Crops & 4.1 & 6.6 & 5 & 10.4 & 11.4 & 8.6 \\
\hline Manufacturing & 16.8 & 17.9 & 20.2 & 33.1 & 33.2 & 40.9 \\
\hline Trade & 10.9 & 12.4 & 13.4 & 23.7 & 23.5 & 20.2 \\
\hline Other Service & 24.1 & 23.1 & 24.6 & 2.6 & 4.6 & 2.0 \\
\hline \multicolumn{1}{|c|}{ Total } & 100.0 & 100 & 100 & 100 & 100 & 100 \\
\hline
\end{tabular}

\begin{tabular}{|l|c|c|c|c|c|c|}
\hline $\begin{array}{c}\text { FACTOR } \\
\text { OUTPUT }\end{array}$ & 1975 & 1980 & 1985 & 1990 & 1995 & 1999 \\
\hline Labor & 46.3 & 48.1 & 52.0 & 50.3 & 53.4 & 51.3 \\
\hline Capital & 53.7 & 51.9 & 48.0 & 49.7 & 46.6 & 48.7 \\
\hline Total & 100 & 100 & 100 & 100 & 100 & 100 \\
\hline
\end{tabular}

production activities and its subsequent effects to the distribution of labor and capital, and institutional income distribution.

In 1975 for example, the impact of an institutional injection generated a share of $45.3 \%$, $17 \%$ and $37.7 \%$ among households, firms and government output respectively. This distribution pattern was almost the same until 1995, but changed significantly in 1999. Further transformation from institutional income to production activities revealed that the largest

\footnotetext{
${ }^{2}$ In the BSPA we did not include the final demand of factors as an exogenous account.
} 
Table 1b. Transformation From Activities to Factors and Institutions, 1975-99 (\%)

\begin{tabular}{|l|r|r|r|r|r|r|}
\hline \multicolumn{1}{|c|}{$\begin{array}{c}\text { F. DEMAND } \\
\text { ACTIVITIES }\end{array}$} & 1975 & 1980 & 1985 & 1990 & 1995 & 1999 \\
\hline Food crops & -16.7 & -9.2 & -15.3 & 4.1 & 5.0 & 20.5 \\
\hline Estate Crops & 3 & 3.6 & -0.3 & 1.2 & 0.8 & 5.0 \\
\hline Manufacturing & 67.6 & 73.3 & 72.8 & 90.0 & 86.8 & 59.1 \\
\hline Trade & 46.1 & 32.5 & 42.1 & 2.9 & 4.9 & 13.6 \\
\hline Other Service & 0 & -0.2 & 0.7 & 1.8 & 2.5 & 1.8 \\
\hline \multicolumn{1}{c|}{ Total } & 100 & 100 & 100 & 100 & 100 & 100 \\
\hline
\end{tabular}

\begin{tabular}{|l|r|r|r|r|r|r|}
\hline $\begin{array}{c}\text { ACTIVITIES } \\
\text { OUTPUT }\end{array}$ & 1975 & 1980 & 1985 & 1990 & 1995 & 1999 \\
\hline Food crops & 30.3 & 21.6 & 21.8 & 19.1 & 19.3 & 26.8 \\
\hline Estate Crops & 5 & 6.6 & 4.1 & 2.7 & 2.9 & 4.4 \\
\hline Manufacturing & 34.1 & 43.3 & 42.7 & 46.9 & 43.5 & 33.7 \\
\hline Trade & 21.3 & 19.2 & 21 & 22.9 & 22.8 & 25.6 \\
\hline Other Service & 9.2 & 9.3 & 10.4 & 8.4 & 11.6 & 9.5 \\
\hline Total & 100 & 100 & 100 & 100 & 100 & 100 \\
\hline
\end{tabular}

\begin{tabular}{|l|r|r|r|r|r|c|}
\hline $\begin{array}{c}\text { FACTOR } \\
\text { OUTPUT }\end{array}$ & 1975 & 1980 & 1985 & 1990 & 1995 & 1999 \\
\hline Labor & 38.9 & 38 & 43.9 & 46.6 & 51.1 & 52.9 \\
\hline Capital & 61.1 & 62 & 56.1 & 53.4 & 48.9 & 47.1 \\
\hline Total & 100.0 & 100 & 100 & 100 & 100 & 100 \\
\hline
\end{tabular}

\begin{tabular}{|l|c|c|c|c|c|c|}
\hline $\begin{array}{c}\text { INSTITUTION } \\
\text { OUTPUT }\end{array}$ & 1975 & 1980 & 1985 & 1990 & 1995 & 1999 \\
\hline Households & 63.9 & 52.8 & 61.4 & 68.5 & 72.0 & 70.6 \\
\hline Firms & 25.4 & 30.5 & 25.2 & 20.2 & 19.9 & 18.6 \\
\hline Government & 10.7 & 16.7 & 13.4 & 11.3 & 8.1 & 10.9 \\
\hline Total & 100 & 100 & 100 & 100 & 100 & 100 \\
\hline
\end{tabular}

part of institutional influence went to food crops during the whole period of 1975 to 1985 , between $36-43 \%$ of activity output. From 1990 to 1999, the share of food crop dropped from $36.8 \%$ to $28 \%$. Compared to other production sectors, estate crops from 1975 to 1985 received the influence that indicated the linkages between the output of estate crops and institutional demand was not strongly related. The transformation of production activities due to the influence of institutional income showed the declining share of food crops from 


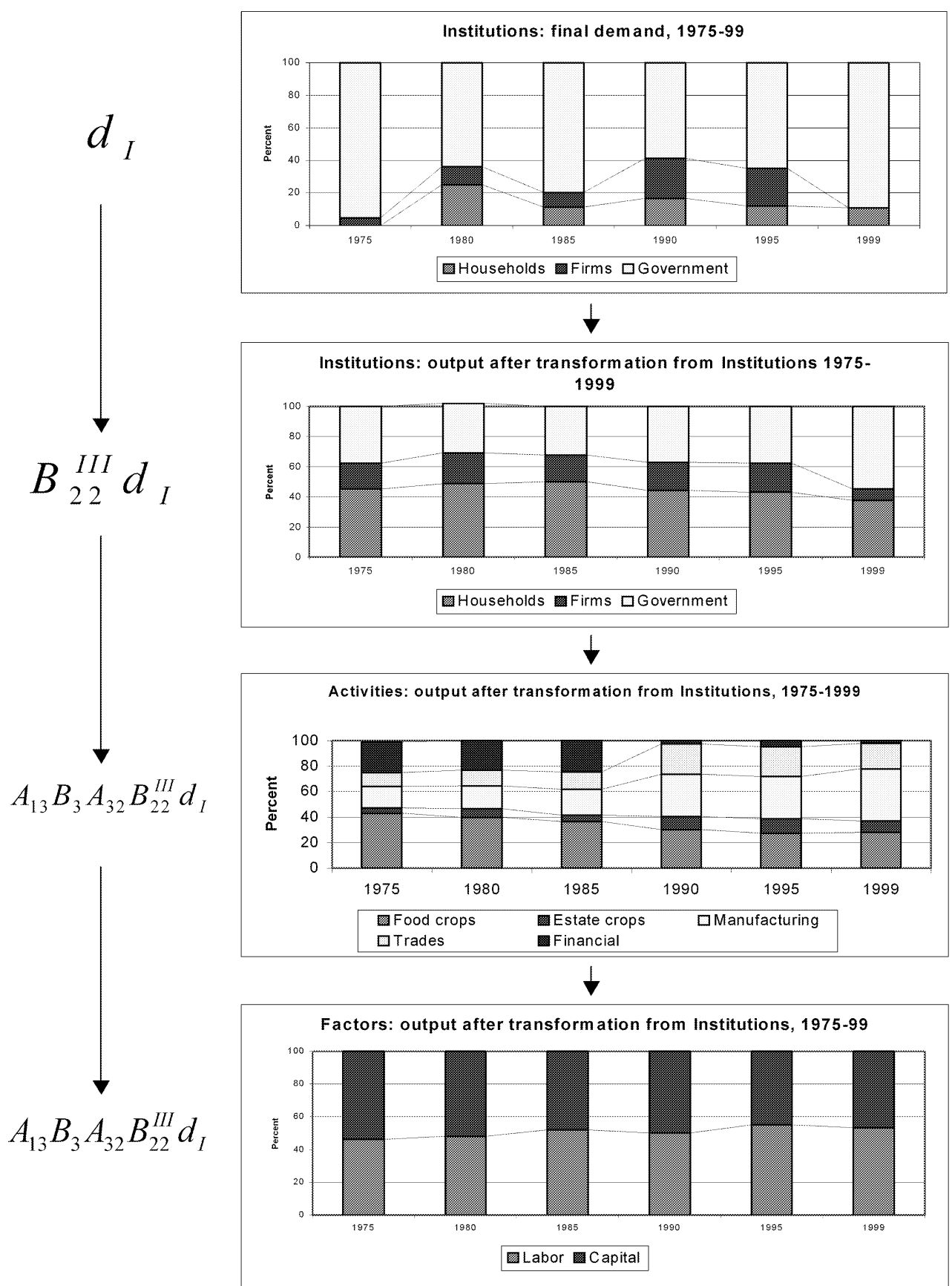

Figure 2a. The Transformation from the Injection of Institution

1975 to 1999 ; they were substituted by manufacturing. This pattern indicated the increasing impact of institutional consumption of and spending on manufacturing products. In the period of financial crisis, the share of food crops rose slightly from $27.4 \%$ in 1995 to $28.3 \%$ in 1999. The share of financial (include government sector) outputs declined significantly 


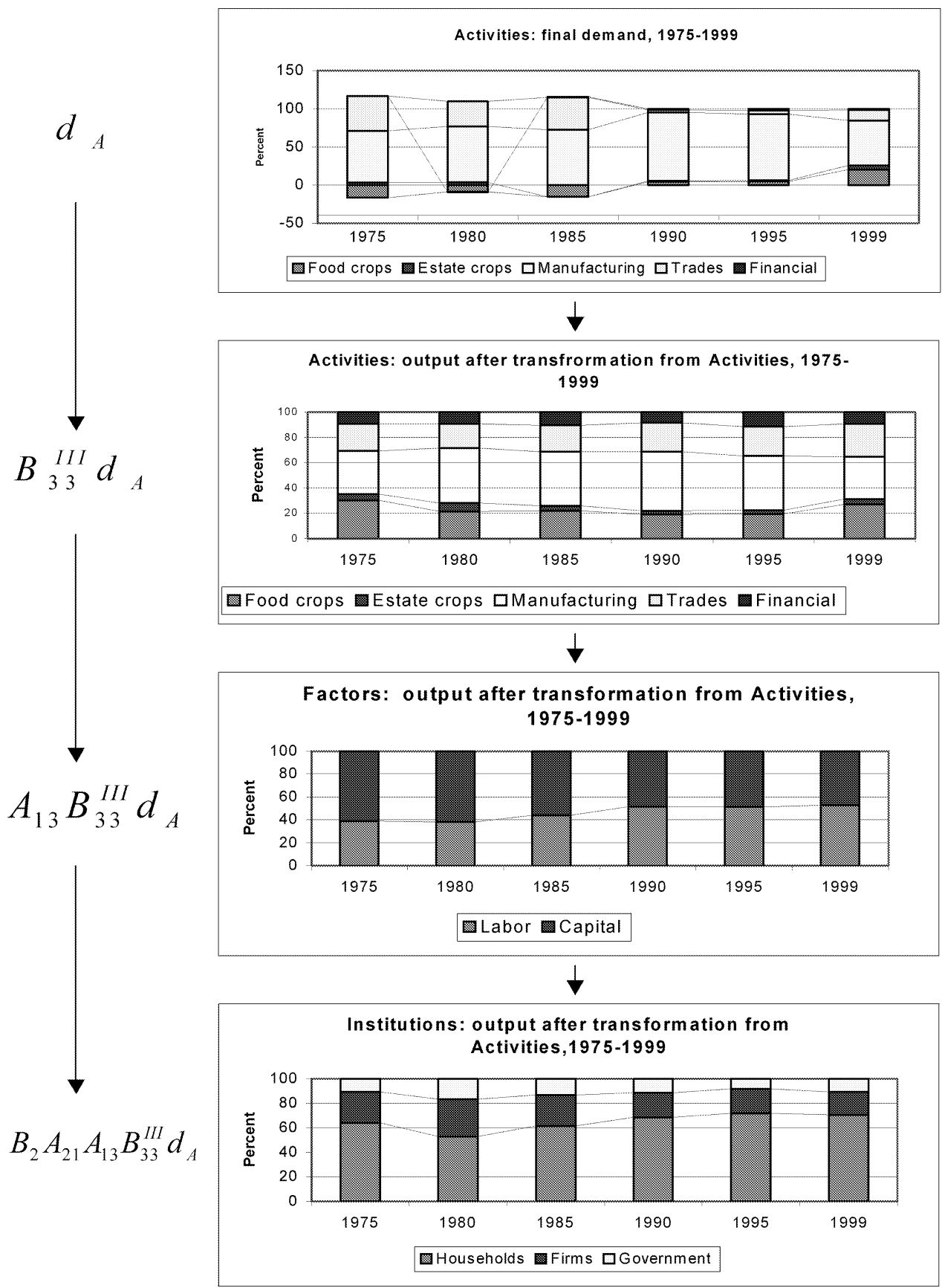

Figure 2b. The transformation from injection of Activities to Factors and Institutions

after 1985 from $23-24 \%$ during $1975-85$ to $2.6 \%$ and $4.6 \%$ respectively in 1995 . In 1999 the share was down to only $2 \%$. This result is interpreted as the declining influence of household consumption, company investment and government expenditure in the financial and government sector; this sector was badly hit by the crisis during which time many commercial 
banks collapsed.

The changing pattern of production activities on factor incomes indicates the increasing share of labor compared to capital. During 1975-1980, the share of capital income was larger than labor income while over the next periods, the share of labor income increased to surpass capital income. The transformation of the influence from institution to production activities and to factors provides a positive effect on the income distribution to labor during the whole period. Given the aggregate nature of this system, nothing can be inferred about the impact on the distribution of income across income groups.

The transformation of production activity to factors of production generally increased the share of labor income between 1975-99. The distribution of labor income in factors of production changed from $38.9 \%$ in 1975 to become $51.7 \%$ in 1990 . Over the period, 1990-1999, labor become has received the lion's share in the factor incomes but the impact of factor income on the transformation of production activity and its subsequent influence on institutional income distribution varied. The share of household income was still the largest from 1975 to 1999 , and the share of companies income dropped significantly from 30.5\% in 1980 to become $18.6 \%$ in 1999 - the lowest level over the whole period.

Using a set of aggregated SAM data, at a macro scale, the results from two initial injections form institution and production activities provide some general features of the structural change in the Indonesia economy over the years from 1975 to 1999. The most important feature of the impact from the initial injection both for institution and activity is the increasing consumption of food crops during the financial crisis in 1999 with the decline in the share of trade, estate crops and financial \& government services, compared to 1995. However, further conclusions about the impact of the crisis on structural changes in the Indonesian economy would need to be confirmed through the analysis of hierarchy of direct coefficient of production activity in the SAM framework with a more detailed level of aggregation and, of course, with analysis five to ten years from the end of the crisis.

An important interpretation from the impact of institutional income to the transformation of production activities is the declining share of food crops consumption, substituted by the increasing share on manufacturing consumption during the period 1975-1995. This consumption pattern follows an Engel curve process whereby a declining portion of income would be spent on food consumption when income per capita rises. In the midst of the crisis in 1999, the share of consumption of food crops rises again due to the decline of real income. In this situation, the influence of the declining institutional income from households, companies and government to production activities provided a significant impact on the financial sector. In 1999, the demand for financial services declined dramatically.

\section{The Decomposition of Goods and Services}

In order to capture the influence and linkages between service sector and the rest of the economy, production activity must be partitioned into goods and services sub-matrices. Two sets of 1995 and $1998(109 \times 109)$ national SAM data were aggregated into 22 consistent sectors. The production activities are: agriculture, mining, manufacturing industries, electricity, gas \& water (EGW), construction, trade, hotel and restaurant, transport, finance, and other service sector. The block matrix of factor of production in the SAM is divided into 
five elements, agricultural labor, production labor, administrative labor, professional labor, and capital and there are five elements in the institution accounts, agricultural households, non-agricultural household rural, non-agricultural household rural, firms, and government (see table 2).

The decomposition of the transaction matrix into goods and service sector is basically to partition $A_{33}$ in the previous equation (1 and 2); the block matrices of the four economic subsystems is displayed as:

$$
A=\left(\begin{array}{cccc}
0 & 0 & 0 & 0 \\
A_{21} & 0 & 0 & 0 \\
0 & 0 & 0 & 0 \\
0 & 0 & 0 & 0
\end{array}\right)+\left(\begin{array}{cccc}
0 & 0 & 0 & 0 \\
0 & A_{22} & 0 & 0 \\
0 & A_{32} & 0 & 0 \\
0 & A_{42} & 0 & 0
\end{array}\right)+\left(\begin{array}{cccc}
0 & 0 & A_{13} & 0 \\
0 & 0 & 0 & 0 \\
0 & 0 & A_{33} & 0 \\
0 & 0 & A_{34} & 0
\end{array}\right)+\left(\begin{array}{cccc}
0 & 0 & 0 & A_{14} \\
0 & 0 & 0 & 0 \\
0 & 0 & 0 & A_{34} \\
0 & 0 & 0 & A_{44}
\end{array}\right)=A_{1}+A_{2}+A_{3}+A_{4}
$$

where, $A_{3}$ and $A_{4}$ represents block matrix of goods and services respectively. Let the previous $A_{i j}$ for $i=3$ or $j=3$ be denoted with subscript $\left(^{*}\right)$. Using equation (23) as the framework, the linkages of the whole economic subsystem with the associated final demand $d$ of each block matrix can be written as:

Table 2. Classification of 1995 and 1998 National SAM (22 x 22)

\begin{tabular}{|c|c|c|c|}
\hline & Sector & Abbreviation & $\begin{array}{l}\text { SAM Aggregation } \\
(109 \times 109)\end{array}$ \\
\hline \multirow{5}{*}{$\begin{array}{c}\text { FACTOR OF } \\
\text { PRODUCTIONS }\end{array}$} & Agricultural Labor & AgLab. & $1-4$ \\
\hline & Production Labor & ProLab & $5-8$ \\
\hline & Administration Labor & AdmLab. & $9-12$ \\
\hline & Professional Labor & ProfLab. & $13-16$ \\
\hline & Capital & Cap. & $17-23$ \\
\hline \multirow{5}{*}{ INSTITUTIONS } & Agricultural Household & $\mathrm{AgHH}$ & $24-27$ \\
\hline & Non-agricultural Household Rural & NagRural & $28-30$ \\
\hline & Non-agricultural Household Urban & NagUrban & $31-33$ \\
\hline & Firms & Firm & 34 \\
\hline & Government & Gov. & 35 \\
\hline \multirow{9}{*}{$\begin{array}{c}\text { PRODUCTION } \\
\text { ACTIVITIES }\end{array}$} & Agriculture & Agri. & $36-40,61-65,84-88$ \\
\hline & Mining & Mining & $41-42,66-67,89-90$ \\
\hline & Manufacturing & Man. & $43-47,68-72,91-95$ \\
\hline & Electricity, Gas, and Water & EGW & $48,73,96$ \\
\hline & Construction & Const. & $49,74,97$ \\
\hline & Trades, Hotels, restaurants & Trade & $50-52,59,75-77,98-100$ \\
\hline & Transportation & Trans. & $53-54,60,78-79,101-102$ \\
\hline & Finance, Real Estate & Finance & $55-56,80-81,103-104$ \\
\hline & Other services & Other & $57-58,82-83,105-106$ \\
\hline
\end{tabular}




$$
\begin{aligned}
B d & =\left[\begin{array}{ccc}
B_{11}^{I V} & A_{1 *} B_{*} A_{*_{2}} B_{22}^{I V} & A_{1 *} B_{* *}^{I V} \\
B_{2} A_{21} B_{11}^{I V} & B_{22}^{I I I} & B_{2} A_{21} A_{1 *} B_{* *}^{I V} \\
B_{*} A_{*_{2}} B_{2} A_{21} B_{11}^{I V} & B_{*} A_{*_{2}} B_{22}^{I V} & B_{* *}^{I V}
\end{array}\right]\left[\begin{array}{c}
0 \\
d_{I} \\
d_{*}
\end{array}\right] \\
& =\left[\begin{array}{c}
A_{1 *} B_{*} A_{*_{2}} \\
I \\
B_{*} A_{*_{2}}
\end{array}\right] B_{22}^{I V} d_{I}+\left[\begin{array}{c}
A_{1 *} \\
B_{2} A_{21} A_{1 *} \\
I
\end{array}\right] B_{* *}^{I V} d_{*}
\end{aligned}
$$

Superscript $I V$ denotes four block matrices of economic subsystems. It can be shown here that:

$$
A_{1 *}=\left(\begin{array}{ll}
A_{13} & A_{14}
\end{array}\right) ; B_{*}=\left(\begin{array}{cc}
B_{3} & 0 \\
0 & B_{4}
\end{array}\right) ; \quad B_{* *}^{I V}=\left(\begin{array}{cc}
B_{33}^{I V} & B_{34}^{I V} \\
B_{43}^{I V} & B_{44}^{I V}
\end{array}\right)
$$

The formation of four block matrices, the final demand of institutions $\left(d_{I}\right)$, goods sector $\left(d_{G}\right)$ and service sector $\left(d_{S}\right)$ is presented in equation (29):

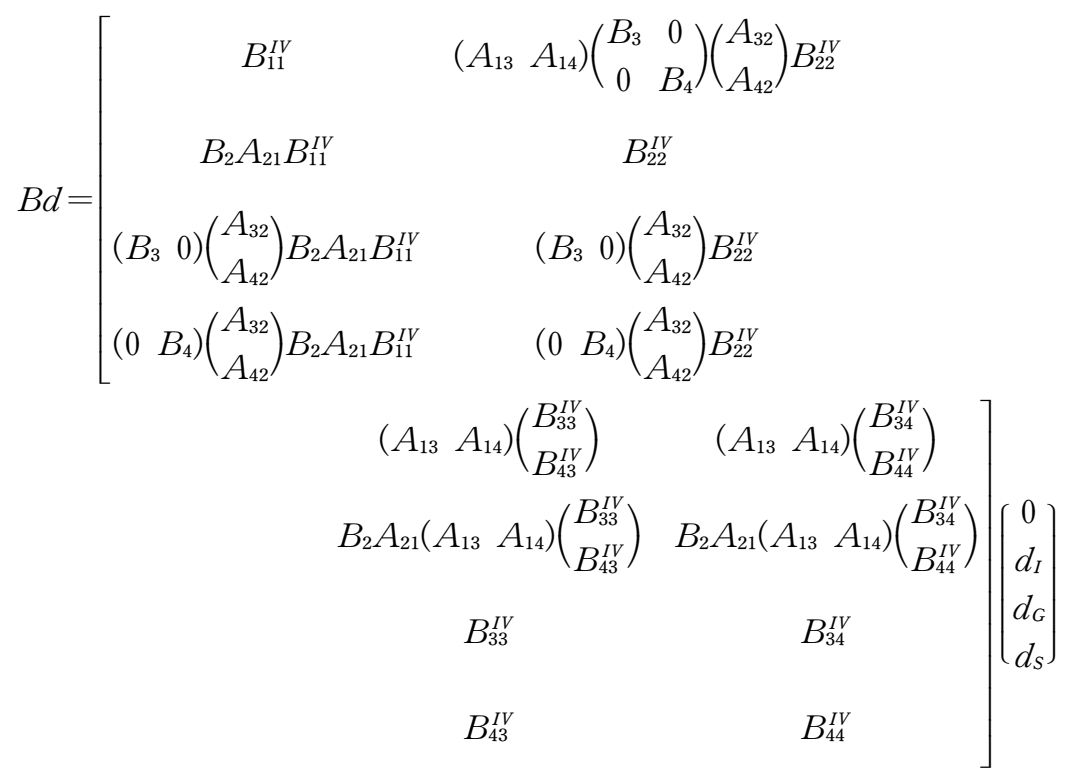

The decomposition of goods and services in equation (29) provides a pseudo block matrix because of the two-way interaction between both sectors as opposed to the one-way interaction between production activities, factors, and institutions economic subsystems. The injection of final demand will create a branching out process between goods and services. Network complication initiated by institutions, goods and services and branching process resulted from the decomposition can be given as:

a). Initial injection from Institutions :

$$
d_{I} \rightarrow B_{22}^{I V} d_{I} \rightarrow \begin{aligned}
& B_{3} A_{32} B_{22}^{I V} d_{I} \rightarrow A_{13} B_{3} A_{32} B_{22}^{I V} d_{I} \\
& B_{4} A_{42} B_{22}^{I V} d_{I} \rightarrow A_{14} B_{4} A_{42} B_{22}^{I V} d_{I}
\end{aligned}
$$

where, $d_{I}, B_{22}^{I V} d_{I}$ is the block matrix of final demand of institutions and the first transformation of institutions respectively. Branching out takes place in the form of $B_{3} A_{32} B_{22}^{I V} d_{I}$ and 
$B_{4} A_{42} B_{22}^{I V} d_{I}$ is the second (goods sectors) and the third transformation (service sector) respectively. Both $A_{13} B_{3} A_{32} B_{22}^{I V} d_{I}$ and $A_{14} B_{4} A_{42} B_{22}^{I V} d_{I}$ are the fourth transformations, generated from goods and services respectively.

b). Initial injection from Goods Sector:

$$
\begin{aligned}
& d_{G} \rightarrow B_{33}^{I V} d_{G} \rightarrow A_{13} B_{33}^{I V} d_{G} \rightarrow B_{2} A_{21} A_{13} B_{13}^{I V} d_{G} \\
& \uparrow \downarrow \\
& B_{43}^{I V} d_{G} \rightarrow A_{13} B_{43}^{I V} d_{G} \rightarrow B_{2} A_{21} A_{13} B_{43}^{I V} d_{G}
\end{aligned}
$$

where, $d_{G}$ is the final demand of goods sector, $B_{33}^{I V} d_{G}$ and $B_{43}^{I V} d_{G}$ are the first and second transformation respectively as a result of branching out process generated by goods sector.

c). Initial injection from Services Sector:

$$
\begin{aligned}
B_{34}^{I V} d_{S} & \rightarrow A_{14} B_{34}^{I V} d_{S} \rightarrow B_{2} A_{21} A_{14} B_{34}^{I V} d_{S} \\
\uparrow \downarrow & \\
d_{S} \rightarrow B_{44}^{I V} d_{S} & \rightarrow A_{14} B_{44}^{I V} d_{S} \rightarrow B_{2} A_{21} A_{14} B_{44}^{I V} d_{S}
\end{aligned}
$$

\section{Empirical Application}

A branching out process generated by goods and service sector in 1995 and 1998 can be seen in tables $3 \mathrm{a}, \mathrm{b}$, and $4 \mathrm{a}, \mathrm{b}$ respectively. In the first transformation, final demand for goods transforms the output of the goods sector itself, and at the same time induces output in the services sector (second transformation). In the next stages, both goods and service sectors transform the composition of factors (third transformation) and institutions (fourth transformation).

Using the final demand of the goods sector as the injector, at the first transformation the goods sector produces Rp.144,708 billion and Rp.376,146 billion of agricultural output in 1995 and 1998 respectively (table 3a and 4a). In 1995, final demand of goods sector directly generated the largest share of the output of goods sector $(63.0 \%)$, with the rest, $37.0 \%$, accounted for by services. In addition to the generation of agriculture, mining and manufacturing, the goods economic subsystem generated $42.2 \%$ of the total output of services; with the rest, $57.8 \%$, generated by services itself. From tables $4 \mathrm{a}$ and $5 \mathrm{~b}$, it can bee seen that the goods sector in 1998 played a more dominant role in generating both goods and services. The goods sector alone produces $78.1 \%$ and $54.7 \%$ of total output of goods and services respectively.

Viewing the data in table $3 \mathrm{~b}$ and $4 \mathrm{~b}$ in more detail, it can be seen that the increasing demand for electricity, gas and water (EGW) that was generated by goods sector increased from $55.9 \%$ in 1995 to $70.1 \%$ in 1998 . Another interesting feature shows that more demand for financial sector was generated by goods sector, from $47.2 \%$ in 1995 to $59.4 \%$ in 1998 . The demand for construction generated by goods producing sector also increased from $3.6 \%$ in 1995 to $22.2 \%$ in 1998 .

The factorial and institutional income distribution is largely generated by the goods sector. In 1995 and 1998, the direct injection from services alone (not including any induced effects from the goods sector) contributed $27.6 \%$ and $17 \%$ of factor income respectively. The declining contribution of services in generating factorial income in 1998 indicated the deterioration of service sector following economic crises that started in mid-1997. Under 
Table 3a. Transformation from Goods 1995 (Rp. Billion)

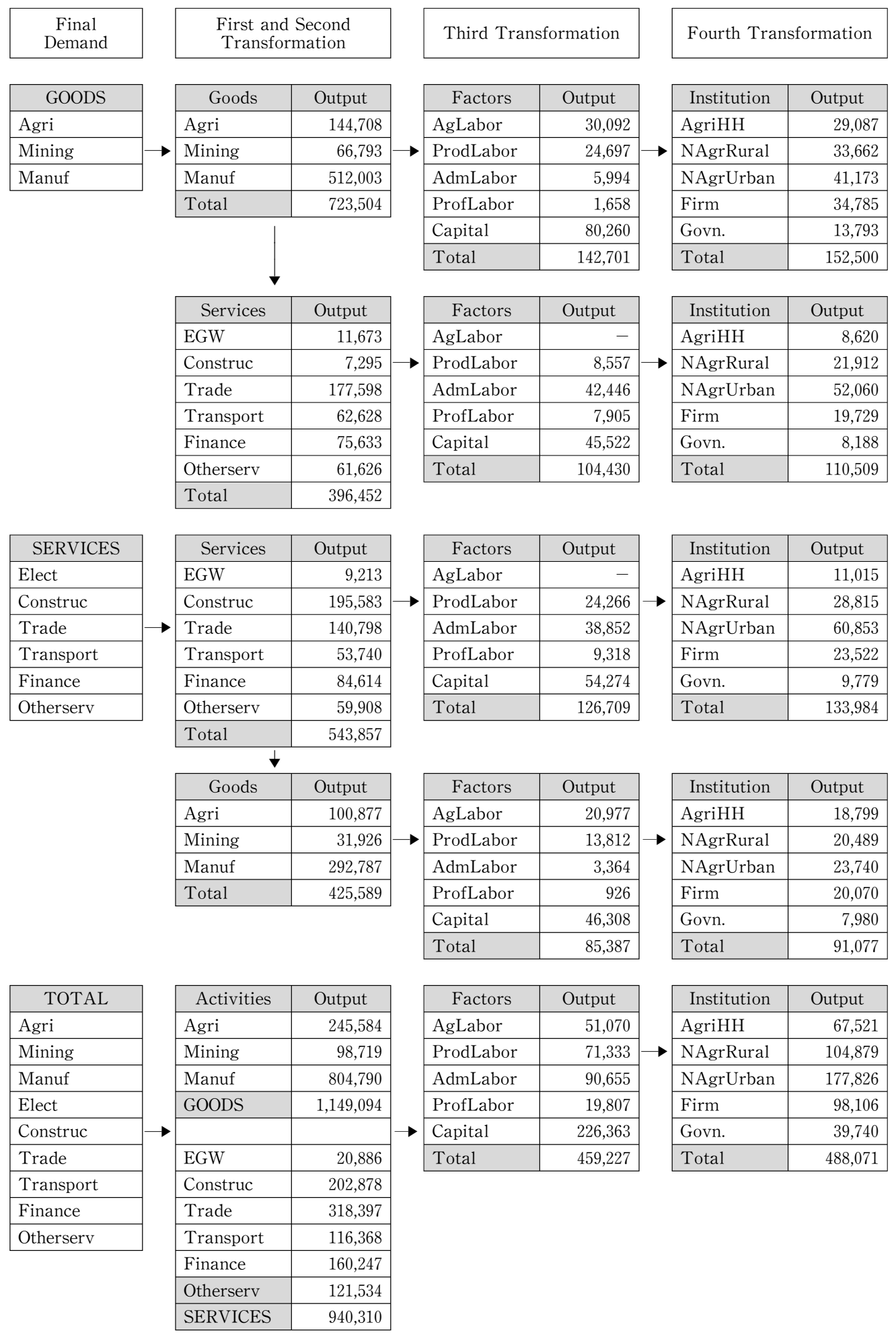


Table 3b. Composition After the Transformation of Goods and Services, 1995 (\%)

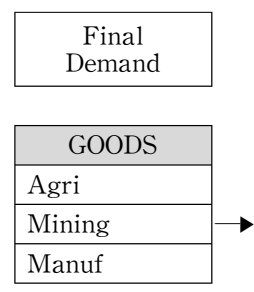

\begin{tabular}{|l|}
\hline \multicolumn{1}{|c|}{ SERVICES } \\
\hline Elect \\
\hline Construc \\
\hline Trade \\
\hline Transport \\
\hline Finance \\
\hline Otherserv \\
\hline
\end{tabular}

\begin{tabular}{|l|}
\hline \multicolumn{1}{|c|}{ TOTAL } \\
\hline Agri \\
\hline Mining \\
\hline Manuf \\
\hline Elect \\
\hline Construc \\
\hline Trade \\
\hline Transport \\
\hline Finance \\
\hline Otherserv \\
\hline
\end{tabular}

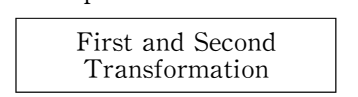

Transformation

\begin{tabular}{|c|c|c|c|c|}
\hline Goods & Output & \multirow{7}{*}{$\rightarrow$} & Factors & Output \\
\hline Agri & 58.9 & & AgLabor & 58.9 \\
\hline Mining & 67.7 & & ProdLabor & 34.6 \\
\hline Manuf & 63.6 & & AdmLabor & 6.6 \\
\hline Total & 63.0 & & ProfLabor & 8.4 \\
\hline & & & Capital & 35.5 \\
\hline & & & Total & 31.1 \\
\hline
\end{tabular}

\begin{tabular}{|l|r|}
\hline \multicolumn{1}{|c|}{ Services } & \multicolumn{1}{c|}{ Output } \\
\hline EGW & 55.9 \\
\hline Construc & 3.6 \\
\hline Trade & 55.8 \\
\hline Transport & 53.8 \\
\hline Finance & 47.2 \\
\hline Otherserv & 50.7 \\
\hline Total & 42.2 \\
\hline
\end{tabular}

\begin{tabular}{|l|r|}
\hline \multicolumn{1}{|c|}{ Services } & \multicolumn{1}{c|}{ Output } \\
\hline EGW & 44.1 \\
\hline Construc & 96.4 \\
\hline Trade & 44.2 \\
\hline Transport & 46.2 \\
\hline Finance & 52.8 \\
\hline Otherserv & 49.3 \\
\hline Total & 57.8 \\
\hline \multicolumn{2}{|c|}{} \\
\hline
\end{tabular}

\begin{tabular}{|l|r|}
\hline \multicolumn{1}{|c|}{ Goods } & \multicolumn{1}{c|}{ Output } \\
\hline Agri & 41.1 \\
\hline Mining & 32.3 \\
\hline Manuf & 36.4 \\
\hline Total & 37.0 \\
\hline
\end{tabular}

\begin{tabular}{|l|r|}
\hline \multicolumn{1}{|c|}{ Activities } & Output \\
\hline Agri & 100 \\
\hline Mining & 100 \\
\hline Manuf & 100 \\
\hline GOODS & 100 \\
\hline & \\
\hline EGW & 100 \\
\hline Construc & 100 \\
\hline Trade & 100 \\
\hline Transport & 100 \\
\hline Finance & 100 \\
\hline Otherserv & 100 \\
\hline SERVICES & 100 \\
\hline
\end{tabular}

Third Transformation

Fourth Transformation

\begin{tabular}{|l|r|}
\hline \multicolumn{1}{|c|}{ Factors } & Output \\
\hline AgLabor & - \\
\hline ProdLabor & 12.0 \\
\hline AdmLabor & 46.8 \\
\hline ProfLabor & 39.9 \\
\hline Capital & 20.1 \\
\hline Total & 22.7 \\
\hline
\end{tabular}$\quad$\begin{tabular}{|l|r|}
\hline Institution & \multicolumn{1}{c|}{ Output } \\
\hline AgriHH & 12.8 \\
\hline NAgrRural & 20.9 \\
\hline NAgrUrban & 29.3 \\
\hline Firm & 20.1 \\
\hline Govn. & 20.6 \\
\hline Total & 22.6 \\
\hline
\end{tabular}

\begin{tabular}{|l|r|}
\hline \multicolumn{1}{|c|}{ Factors } & Output \\
\hline AgLabor & - \\
\hline ProdLabor & 34.0 \\
\hline AdmLabor & 42.9 \\
\hline ProfLabor & 47.0 \\
\hline Capital & 24.0 \\
\hline Total & 27.6 \\
\cline { 1 - 1 }
\end{tabular}$\rightarrow$\begin{tabular}{|l|r|}
\hline Institution & \multicolumn{1}{c|}{ Output } \\
\hline AgriHH & 16.3 \\
\hline NAgrRural & 27.5 \\
\hline NAgrUrban & 34.2 \\
\hline Firm & 24.0 \\
\hline Govn. & 24.6 \\
\hline Total & 27.5 \\
\hline
\end{tabular}

\begin{tabular}{|l|r|}
\hline \multicolumn{1}{|c|}{ Factors } & Output \\
\hline AgLabor & 41.1 \\
\hline ProdLabor & 19.4 \\
\hline AdmLabor & 3.7 \\
\hline ProfLabor & 4.7 \\
\hline Capital & 20.5 \\
\hline Total & 18.6 \\
\hline
\end{tabular}$\quad$\begin{tabular}{|l|r|}
\hline Institution & \multicolumn{1}{c|}{ Output } \\
\hline AgriHH & 27.8 \\
\hline NAgrRural & 19.5 \\
\hline NAgrUrban & 13.4 \\
\hline Firm & 20.5 \\
\hline Govn. & 20.1 \\
\hline Total & 18.7 \\
\hline
\end{tabular}

\begin{tabular}{|l|r|}
\hline \multicolumn{1}{|c|}{ Factors } & Output \\
\hline AgLabor & 100 \\
\hline ProdLabor & 100 \\
\hline AdmLabor & 100 \\
\hline ProfLabor & 100 \\
\hline Capital & 100 \\
\hline Total & 100 \\
\hline
\end{tabular}

\begin{tabular}{|l|r|}
\hline \multicolumn{1}{|c|}{ Institution } & Output \\
\hline AgriHH & 100 \\
\hline NAgrRural & 100 \\
\hline NAgrUrban & 100 \\
\hline Firm & 100 \\
\hline Govn. & 100 \\
\hline Total & 100 \\
\hline
\end{tabular}


Table 4a. Transformation from Goods and Services 1998 (Rp. Billion)

\begin{tabular}{|l|}
\hline $\begin{array}{c}\text { Final } \\
\text { Demand }\end{array}$ \\
\hline \multicolumn{1}{|c|}{ GOODS } \\
\hline Agri \\
\hline Mining \\
\hline Manuf \\
\hline
\end{tabular}
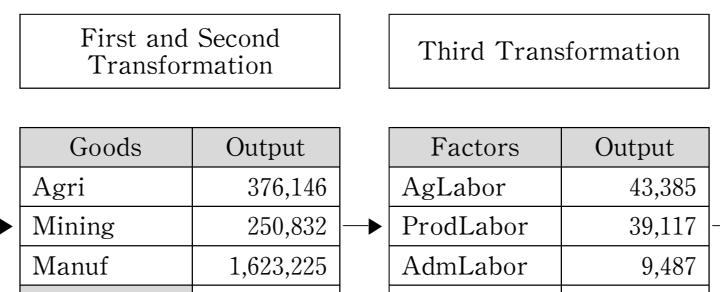

Fourth Transformation

\begin{tabular}{|l|r|}
\hline \multicolumn{1}{|c|}{ Goods } & \multicolumn{1}{c|}{ Output } \\
\hline Agri & 376,146 \\
\hline Mining & 250,832 \\
\hline Manuf & $1,623,225$ \\
\hline Total & $2,250,203$ \\
\hline
\end{tabular}

\begin{tabular}{|c|c|c|c|}
\hline Output & \multirow{7}{*}{$\rightarrow$} & Institution & Output \\
\hline 43,385 & & AgriHH & 66,162 \\
\hline 39,117 & & NAgrRural & 87,634 \\
\hline 9,487 & & NAgrUrban & 112,488 \\
\hline 2,809 & & Firm & 142,568 \\
\hline 335,865 & & Govn. & 51,079 \\
\hline 430,663 & & Total & 459,930 \\
\hline
\end{tabular}

\begin{tabular}{|l|r|}
\hline \multicolumn{1}{|c|}{ Services } & Output \\
\hline EGW & 39,379 \\
\hline Construc & 76,357 \\
\hline Trade & 385,155 \\
\hline Transport & 141,296 \\
\hline Finance & 144,556 \\
\hline Otherserv & 138,268 \\
\hline Total & 925,010 \\
\hline
\end{tabular}

\begin{tabular}{|l|r|}
\hline \multicolumn{1}{|c|}{ Factors } & Output \\
\hline AgLabor & - \\
\hline ProdLabor & 14,079 \\
\hline AdmLabor & 53,866 \\
\hline ProfLabor & 10,277 \\
\hline Capital & 130,041 \\
\hline Total & 208,263 \\
\hline
\end{tabular} \begin{tabular}{|l|r|}
\hline Institution & \multicolumn{1}{c|}{ Output } \\
\hline AgriHH & 19,939 \\
\hline NAgrRural & 41,433 \\
\hline NagrUrban & 83,557 \\
\hline Firm & 55,200 \\
\hline Govn. & 20,399 \\
\hline Total & 220,528 \\
\hline
\end{tabular}

\begin{tabular}{|c|c|c|c|c|c|c|c|c|c|}
\hline SERVICES & \multirow{7}{*}{$\rightarrow$} & Services & Output & \multirow{7}{*}{$\rightarrow$} & Factors & Output & \multirow{7}{*}{$\rightarrow$} & Institution & Output \\
\hline Elect & & EGW & 16,799 & & AgLabor & - & & AgriHH & 15,537 \\
\hline Construc & & Construc & 266,837 & & ProdLabor & 16,882 & & NAgrRural & 31,676 \\
\hline Trade & & Trade & 215,559 & & AdmLabor & 32,256 & & NAgrUrban & 59,858 \\
\hline Transport & & Transport & 87,746 & & ProfLabor & 6,936 & & Firm & 42,224 \\
\hline Finance & & Finance & 98,659 & & Capital & 99,472 & & Govn. & 15,548 \\
\hline Otherserv & & Otherserv & 80,864 & & Total & 155,546 & & Total & 164,842 \\
\hline
\end{tabular}

Total $\quad r \mid$
\begin{tabular}{|l|r|}
\hline \multicolumn{1}{|c|}{$\downarrow$} \\
Goods & \multicolumn{1}{c|}{ Output } \\
\hline Agri & 24,951 \\
\hline Mining & 52,459 \\
\hline Manuf & 454,572 \\
\hline Total & 631,983 \\
\hline
\end{tabular}

\begin{tabular}{|c|c|c|c|c|}
\hline Factors & Output & \multirow{7}{*}{$\rightarrow$} & Institution & Output \\
\hline AgLabor & 14,412 & & AgriHH & 19,521 \\
\hline ProdLabor & 10,622 & & NAgrRural & 24,846 \\
\hline AdmLabor & 2,563 & & NAgrUrban & 30,852 \\
\hline ProfLabor & 753 & & Firm & 38,954 \\
\hline Capital & 91,770 & & Govn. & 13,976 \\
\hline Total & 120,120 & & Total & 128,150 \\
\hline
\end{tabular}

\begin{tabular}{|c|c|c|c|}
\hline TOTAL & \multirow{13}{*}{$\rightarrow$} & Activities & Output \\
\hline Agri & & Agri & 501,097 \\
\hline Mining & & Mining & 303,291 \\
\hline Manuf & & Manuf & $2,077,798$ \\
\hline Elect & & GOODS & $2,882,186$ \\
\hline Construc & & & \\
\hline Trade & & EGW & 56,178 \\
\hline Transport & & Construc & 343,193 \\
\hline Finance & & Trade & 600,714 \\
\hline \multirow[t]{4}{*}{ Otherserv } & & Transport & 229,042 \\
\hline & & Finance & 243,215 \\
\hline & & Otherserv & 219,132 \\
\hline & & SERVICE & $1,691,474$ \\
\hline
\end{tabular}

\begin{tabular}{|c|c|c|c|}
\hline Output & \multirow{7}{*}{$\rightarrow$} & Institution & Output \\
\hline 57,797 & & AgriHH & 121,159 \\
\hline 80,700 & & NAgrRural & 185,588 \\
\hline 98,172 & & NAgrUrban & 286,755 \\
\hline 20,776 & & Firm & 278,947 \\
\hline 657,149 & & Govn. & 101,002 \\
\hline 914,593 & & Total & 973,451 \\
\hline
\end{tabular}


Table 4b. Composition After Transformation of Goods and Services, 1998 (\%)

\begin{tabular}{|l|}
\hline $\begin{array}{c}\text { Final } \\
\text { Demand }\end{array}$ \\
\hline GOODS \\
\hline Agri \\
\hline Mining \\
\hline Manuf \\
\hline
\end{tabular}
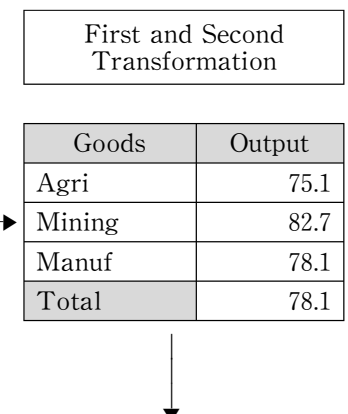

\begin{tabular}{|l|r|}
\hline \multicolumn{1}{|c|}{ Services } & \multicolumn{1}{c|}{ Output } \\
\hline EGW & 70.1 \\
\hline Construc & 22.2 \\
\hline Trade & 64.1 \\
\hline Transport & 61.7 \\
\hline Finance & 59.4 \\
\hline Otherserv & 63.1 \\
\hline Total & 54.7 \\
\hline
\end{tabular}

\begin{tabular}{|l|}
\hline \multicolumn{1}{|c|}{ SERVICES } \\
\hline Elect \\
\hline Construc \\
\hline Trade \\
\hline Transport \\
\hline Finance \\
\hline Otherserv \\
\hline
\end{tabular}

\begin{tabular}{|l|r|}
\hline \multicolumn{1}{|c|}{ Services } & Output \\
\hline EGW & 29.9 \\
\hline Construc & 77.8 \\
\hline Trade & 35.9 \\
\hline Transport & 38.3 \\
\hline Finance & 40.6 \\
\hline Otherserv & 36.9 \\
\hline Total & 45.3 \\
\hline \multicolumn{2}{|c|}{$\downarrow$} \\
\hline \multicolumn{1}{|c|}{ Goods } & Output \\
\hline Agri & 24.9 \\
\hline Mining & 17.3 \\
\hline Manuf & 21.9 \\
\hline Total & 21.9 \\
\hline
\end{tabular}

\begin{tabular}{|c|c|c|}
\hline TOTAL & Activities & Output \\
\hline Agri & Agri & 100 \\
\hline Mining & Mining & 100 \\
\hline Manuf & Manuf & 100 \\
\hline Elect & GOODS & 100 \\
\hline Construc & & \\
\hline Trade & EGW & 100 \\
\hline Transport & Construc & 100 \\
\hline Finance & Trade & 100 \\
\hline \multirow[t]{4}{*}{ Otherserv } & Transport & 100 \\
\hline & Finance & 100 \\
\hline & Otherserv & 100 \\
\hline & SERVICES & 100 \\
\hline
\end{tabular}

Third Transformation

Fourth Transformation

\begin{tabular}{|c|c|c|c|c|}
\hline Factors & Output & \multirow{7}{*}{$\rightarrow$} & Institution & Output \\
\hline AgLabor & 75.1 & & AgriHH & 54.6 \\
\hline ProdLabor & 48.5 & & NAgrRural & 47.2 \\
\hline AdmLabor & 9.7 & & NAgrUrban & 39.2 \\
\hline ProfLabor & 13.5 & & Firm & 51.1 \\
\hline Capital & 51.1 & & Govn. & 50.6 \\
\hline Total & 47.1 & & Total & 47.2 \\
\hline
\end{tabular}

\begin{tabular}{|c|c|c|c|}
\hline Factors & Output & Institution & Output \\
\hline AgLabor & - & AgriHH & 16.5 \\
\hline ProdLabor & $17.4 \rightarrow$ & NAgrRural & 22.3 \\
\hline AdmLabor & 54.9 & NAgrUrban & 29.1 \\
\hline ProfLabor & 49.5 & Firm & 19.8 \\
\hline Capital & 19.8 & Govn. & 20.2 \\
\hline Total & 22.8 & Total & 22.7 \\
\hline
\end{tabular}

\begin{tabular}{|l|r|r|r|}
\hline \multicolumn{1}{|c|}{ Factors } & \multicolumn{1}{|c|}{ Output } \\
\hline AgLabor & - \\
\hline ProdLabor & 20.9 \\
\hline AdmLabor & 32.9 \\
\hline ProfLabor & 33.4 \\
\hline Capital & 15.1 \\
\hline Total & 17.0 \\
\hline
\end{tabular}$\quad$\begin{tabular}{|l|r|}
\hline Institution & \multicolumn{1}{c|}{ Output } \\
\hline AgriHH & 12.8 \\
\hline NAgrRural & 17.1 \\
\hline NAgrUrban & 20.9 \\
\hline Firm & 15.1 \\
\hline Govn. & 15.4 \\
\hline Total & 16.9 \\
\hline
\end{tabular}

\begin{tabular}{|l|r|}
\hline \multicolumn{1}{|c|}{ Factors } & Output \\
\hline AgLabor & 24.9 \\
\hline ProdLabor & 13.2 \\
\hline AdmLabor & 2.6 \\
\hline ProfLabor & 3.6 \\
\hline Capital & 14.0 \\
\hline Total & 13.1 \\
\hline
\end{tabular}$\rightarrow$\begin{tabular}{|l|r|}
\hline Institution & \multicolumn{1}{c|}{ Output } \\
\hline AgriHH & 16.1 \\
\hline NAgrRural & 13.4 \\
\hline NAgrUrban & 10.8 \\
\hline Firm & 14.0 \\
\hline Govn. & 13.8 \\
\hline Total & 13.2 \\
\hline
\end{tabular}

\begin{tabular}{|l|r|}
\hline \multicolumn{1}{|c|}{ Factors } & Output \\
\hline AgLabor & 100 \\
\hline ProdLabor & 100 \\
\hline AdmLabor & 100 \\
\hline ProfLabor & 100 \\
\hline Capital & 100 \\
\hline Total & 100 \\
\cline { 3 - 4 }
\end{tabular}$\rightarrow$\begin{tabular}{|l|r|}
\hline Institution & Output \\
\hline AgriHH & 100 \\
\hline NAgrRural & 100 \\
\hline NAgrUrban & 100 \\
\hline Firm & 100 \\
\hline Govn. & 100 \\
\hline Total & 100 \\
\hline
\end{tabular}


these conditions, the goods sector alone contributed $47.5 \%$ of total institutional income in the economic system. Together with induced services, the injection of goods sector contributes $67 \%$ of total institutional income.

Tables $5 \mathrm{a}$ and $5 \mathrm{~b}$ display the output and the composition of production activities and factor income created by initial transformation from institutions in 1995 and 1998 respectively. The comparison between 1995 and 1998 shows a great difference in the structure of the economy. The government output was decreased dramatically from $38.8 \%$ in 1995 to $18.8 \%$ of total institutional output in 1998, replaced by firms who saw their contribution rise from $18.4 \%$ in 1995 to $25.2 \%$ in 1998 . With this structure, the share of manufacturing output in

Table 5a. Transformation from Institution 1995 and 1998 (Rp. Billion)

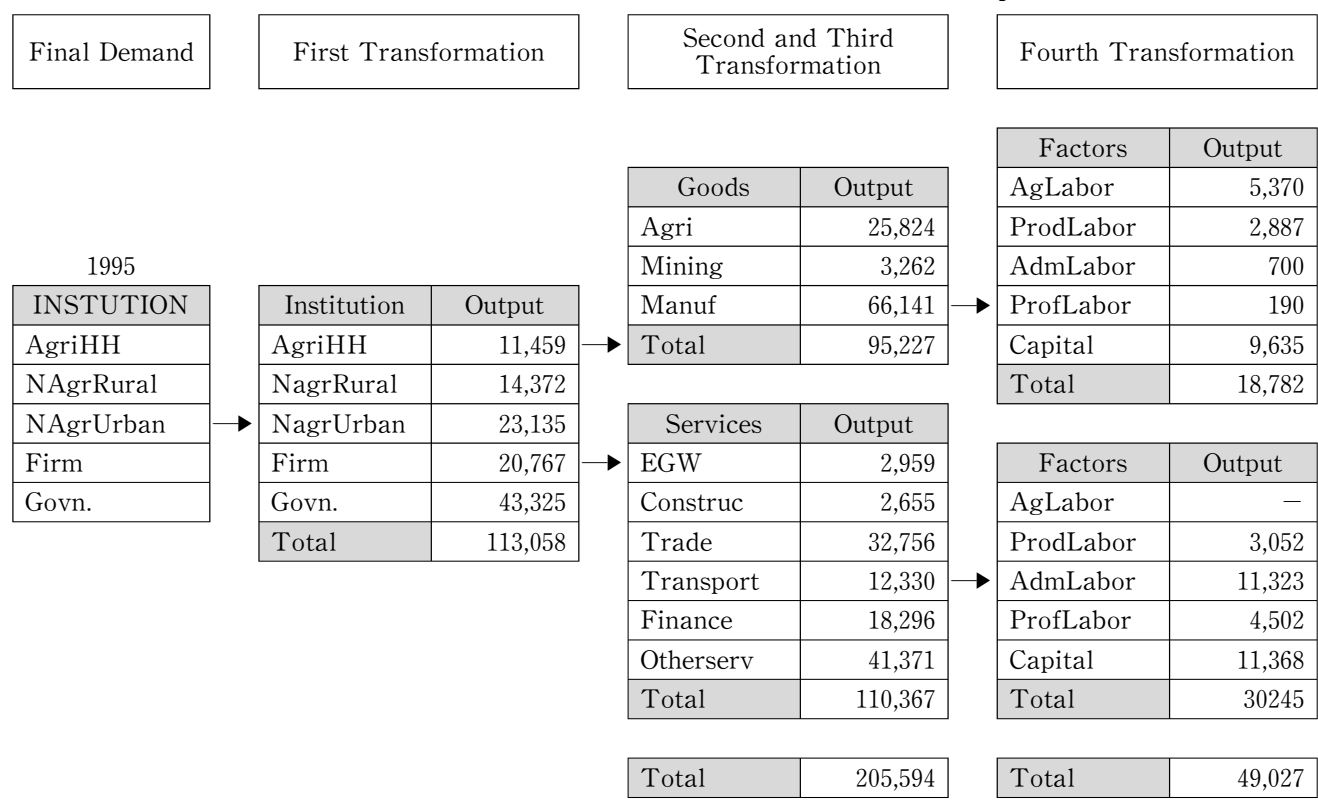

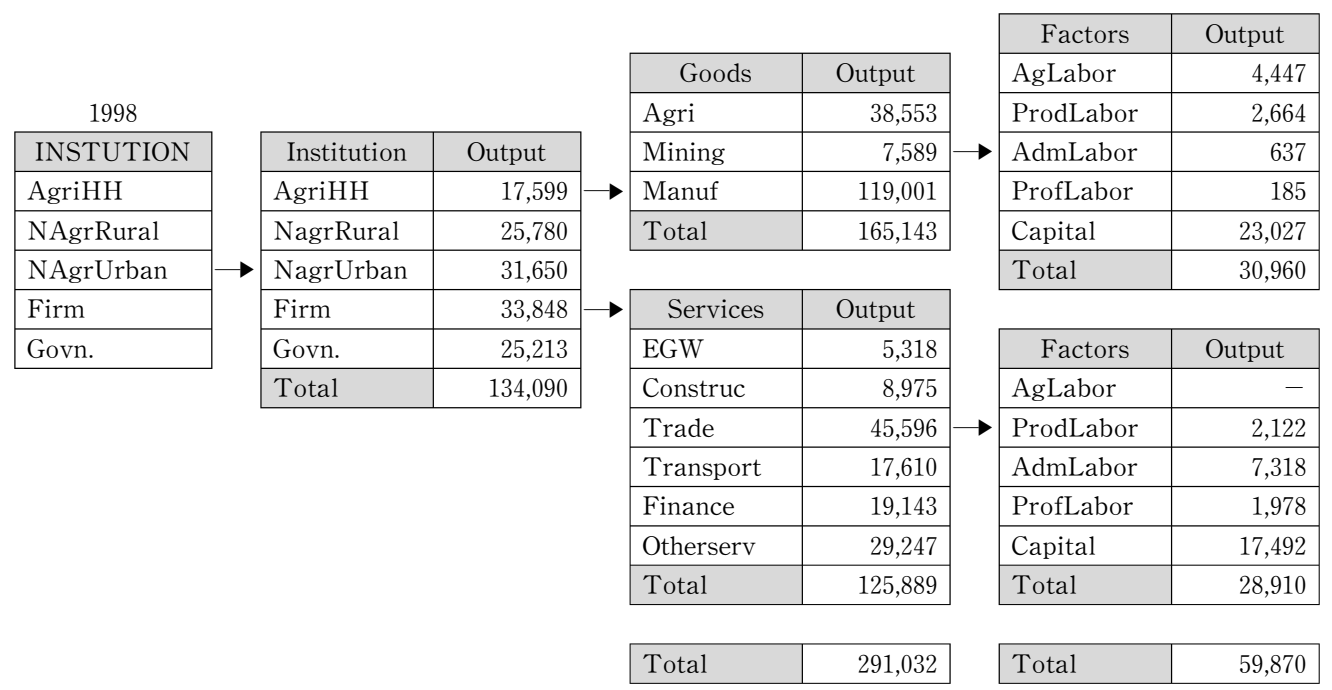


Table 5b. Transformation from Institution 1995 and 1998 (\%)

\begin{tabular}{|c|c|c|c|c|c|c|c|c|c|}
\hline Final Demand & & \multicolumn{2}{|c|}{ First Transformation } & & \multicolumn{2}{|c|}{$\begin{array}{l}\text { Second and Third } \\
\text { Transformation }\end{array}$} & & \multicolumn{2}{|c|}{ Fourth Transformation } \\
\hline \multirow[b]{4}{*}{1995} & \multirow{16}{*}{$\rightarrow$} & & & \multirow{8}{*}{$\rightarrow$} & & & \multirow{7}{*}{$\rightarrow$} & Factors & Output \\
\hline & & & & & Goods & Output & & AgLabor & 11.0 \\
\hline & & & & & Agri & 12.6 & & ProdLabor & 5.9 \\
\hline & & & & & Mining & 1.6 & & AdmLabor & 1.4 \\
\hline INSTUTION & & Institution & Output & & Manuf & 32.2 & & ProfLabor & 0.4 \\
\hline AgriHH & & AgriHH & 10.1 & & Total & 46.3 & & Capital & 19.7 \\
\hline NAgrRural & & NagrRural & 12.7 & & & & & Total & 38.3 \\
\hline NAgrUrban & & NagrUrban & 20.5 & & Services & Output & \multirow{8}{*}{$\rightarrow$} & & \\
\hline Firm & & Firm & 18.4 & \multirow{8}{*}{$\rightarrow$} & EGW & 1.4 & & Factors & Output \\
\hline \multirow[t]{7}{*}{ Govn. } & & Govn. & 38.3 & & Construc & 1.3 & & AgLabor & - \\
\hline & & Total & 100 & & Trade & 15.9 & & ProdLabor & 6.2 \\
\hline & & & & & Transport & 6.0 & & AdmLabor & 23.1 \\
\hline & & & & & Finance & 8.9 & & ProfLabor & 9.2 \\
\hline & & & & & Otherserv & 20.1 & & Capital & 23.2 \\
\hline & & & & & Total & 53.7 & & Total & 61.7 \\
\hline & & & & & Total & 100 & & Total & 100 \\
\hline
\end{tabular}

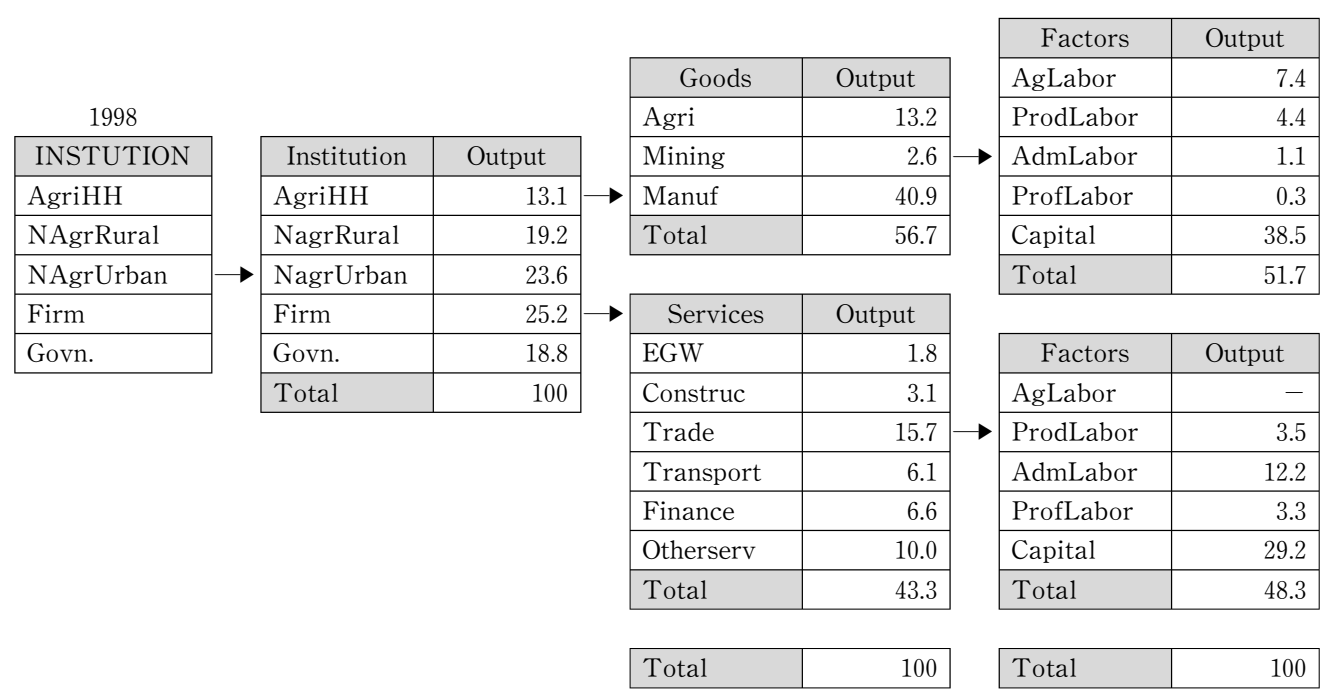

production activities was augmented from $32.2 \%$ in 1995 to $40.9 \%$ in 1998 and this lead to increased capital accumulation from $51.3 \%$ to $74.4 \%$. There is a clear indication of an increasing role for production activities in driving the many of the economic subsystems, directly and indirectly.

\section{Conclusions}

The application of BSPA and the decomposition of production activities into goods and services in a more disaggregated SAM framework provide the capability to examine the contributions of these two sectors to the economy both directly and through the myriad paths 
of indirect interaction that characterize a SAM system of accounts. With BSPA, it is possible to examine the various feedback loop processes as well; taken together, the picture that emerges is one in which there are strong indications of the dominant role of the goods sector in shaping the formation and development of the Indonesian economy. There was a clear indication of the deterioration of the role of the service sector in the Indonesian economy following the mid-1997 economic crisis. While there are some controversies centering on the causal links between goods and services in the modern economies, the analysis is this paper has shown the magnitude of the linkages between both sectors. The goods sector has played a dominant role in changing the output of all production activities, factorial and institutional incomes.

The creation of SAMs in the next decade will provide an opportunity to explore the degree to which the Indonesian economy returns to its former (pre financial crisis) structure and continues to change in the same directions indicative of the period from the 1970s through mid 1990s. What the present SAM structure is unable to capture is the important role played by the informal sector in serving to mute the impact of some of the changes generated by the financial crisis; as Nazara [13] has shown, many employees laid off from jobs in the formal sector retreated into the informal sector in an attempt to maintain household welfare levels. Many also returned to the agricultural sectors.

\section{References}

[1] Achjar, Nuzul, "Structural Changes in the Indonesian Economy and Network Complication." Paper presented at North American Regional Science Conference, at Charleston, South Carolina, November, 2001.

[2 ] Alexander, Jennifer and Booth, Anne, "The Service Sector," in Booth, Anne (ed.). The Oil Boom After, Indonesian Economic Policy and Performance in the Soeharto Era, New York: Oxford University Press, 1992.

[ 3 ] Azis, I.J., "Simulating Economy-Wide Models to Capture the Transition from Financial Crisis to Social Crisis," The Annals of Regional Science, 34, 2001, pp. 251-278.

[4] Bailly, A.S., Mailat, D. and Coffey, W.J., "Service Activities and Regional Development: Some European Examples". Environment and Planning A, 19, 1987, pp. 653-668.

[5] Bailly, Antoine S. and Coffey, William, "The Role of the Service Sector in the Economy of Metropolitan Geneva, 1975-1985”. Review of Urban and Regional Development Studies. 3, 1991, pp. $134-151$.

[6] Behuria, S. and Khullar, R., Intermediate Service and Economic Development: the Malaysian example, Asian Development Bank, Occasional Papers No. 8, 1994.

[ 7 ] Defourny, J. and Thorbecke, E., "Structural Path Analysis and Multiplier Decomposition within a Social Accounting Framework," Economic Journal, 94, 1984, pp. 111-136.

[ 8 ] Ihara, Takeo, "Diagnosis and Therapy of Interregional Feedback Effects," in Hewings, G.J.D., Sonis, M., Madden, M. and Kimura, Y. (eds.), Understanding and Interpreting Economic Structure. New York: Springer-Verlag, 1999, pp. 263-286.

[9] Khan, H.A. and Thorbecke, E., Macroeconomic Effects and Diffusion of Alternative Technologies within a Social Accounting Matrix Framework, Aldershot: Gower, 1988.

[10] Manning, C., The Forgotten Sector : Service Sector Employment in Indonesia, Jakarta: ILO and Department of Manpower, 1992.

[11] Miyazawa, K., "Internal and External Matrix Multipliers in the Input-Output Model", Hitotsubashi Journal of Economics, 7, 1966, pp. 38-55. 
[12] Miyazawa, Kenichi, Input-Output Analysis and the Structure of Income Distribution, New York: Springer-Verlag, 1976.

[13] Nazara, Suahasil, "Determinants of Lay-offs During the Indoensian Economic Crisis with Special Attention to Spatial Effects," Discussion Paper 03-T-12, Regional Economics Applications Laboratory, University of Illinois, Urbana, www.uiuc.edu/unit/real, 2003.

[14] Pyatt, Graham and Round, J.I., "Accounting and Fixed Price Multipliers in a Social Accounting Matrix Framework,” Economic Journal, 89, 1979, pp. 850-873.

[15] Riddle, Dorothy I., Service-led Growth: The Role of Services Sector in World Development, New York, Praeger, 1986.

[16] Sonis, M. and Hewings, G.J.D., "Fields of Influence and Extended Input-Output Analysis: A Theoretical Account," in Dewhurst, J.J.LI., Hewings, G.J.D., and Jensen Rodney, C. (eds.), Regional Input-Output Modelling: New Developments and Interpretations, Aldershot: Avebury, 1991.

[17] Sonis, M., Hewings, G.J.D. and Sulistyowati, Sri, "Block Structural Path Analysis: Applications to Structural Changes in the Indonesian Economy," Economic Systems Research, 9, 1997, pp. 265280 .

[18] Sonis, M., Hewings, Geoffrey J.D., "Economic Complexity as Network Complication: Multiregional Input-Output Structural Path Analysis," The Annals of Regional Science, 32, 1998, pp. 407436.

[19] Stahl, Charles W., The Impact of Structural Change on APEC Labor Market and Their Implications for International Labor Migration, in Proceeding of the International Workshop on International Migration and Structural Change in the APEC Member Economies, China Taipei, October 19-20, 2001, Chiba, Japan: Institute of Developing Economies, JETRO.

[20] Yamada, H. and Ihara, T., Input-Output Analysis of Interregional Repercussion, Papers and Proceedings of the Third Far East Conference of the Regional Science Association, 1969. 